\title{
Management of Powdery Mildew of Bottle Gourd (Lagenaria siceraria) through Fungicide and Natural Products
}

\author{
Apurvkumar Patel, M. L. Tetarwal* and R. L. Meena
}

Department of Plant Pathology, Sardarkrushinagar Dantiwada Agricultural University, Sardarkrushinagar, India

*Corresponding author

\section{A B S T R A C T}

\section{Keywords}

Podosphaera

fuliginea,

Lagenaria

siceraria,

Management,

fungicides, Natural

products

Article Info

Accepted:

04 November 2020

Available Online:

10 December 2020
All the fungicides tested found significantly promising in reduction powdery mildew intensity of bottle gourd with increasing fruit yield as compared to untreated control. Minimum powdery mildew intensity with maximum fruit yield was observed in Propiconazole followed by Wettable sulphur and Tebuconazole + Trifloxystrobin. All the natural products were found effective in controlling the disease significantly over the control.

\section{Introduction}

Bottle gourd (Lagenaria siceraria) is a cosmopolitan cucurbitaceous vegetable grown successfully in tropical and sub-tropical regions. It has worldwide demand for vegetable as well as medicinally uses. It is extensively grown in India and cultivated almost universally throughout the year. Powdery mildew is the most serious one causing great damage to the crop yield. Present study was undertaken to evaluate some fungicides and natural products against powdery mildew of bottle gourd caused by Podosphaera fuliginea.

\section{Materials and Methods}

The study was conducted in 2018-19 to test the effect of fungicides and natural products for managing the powdery mildew of bottle gourd caused by Podosphaera fuliginea under field conditions. An experiment was conducted in Randomised Block Design. Required quantities of fungicides (Wettable sulphur $80 \%$ WP, Dinocap $48 \%$ EC, 
Propiconazole $25 \%$ EC, Azoxystrobin $25 \%$ EC, Tebuconazole $55 \%$ + Trifloxystrobin 25 $\% \mathrm{WG}$ ) and natural products (Fermented cow urine 20\%, Fermented butter milk 20\%, Fermented leaf-extract of neem, dhatura, sitafal 20\%, Fermented cow urine, butter milk, leaves of (neem, dhatura, sitafal) in combination $20 \%$ Bioformulation of Trichoderma harzianum $2 \times 10^{6} \mathrm{cfu} / \mathrm{g}$ ). The plots under experimentation were visited daily to observe the first appearance of the disease symptom in the field. The first spray was given at the initiation of disease in field, and remaining one spray of fungicides was carried out at 15 days interval. Control was maintained by water spraying (400 lit/ha) and without spraying of any fungicides. Observations on disease intensity were recorded from randomly selected five plants from each treatment after seven days of last spray using 0-4 scale given by Gangopadhyay (1984). Each plant was evaluated for its disease reaction by scoring the disease severity on top, middle and lower leaves following a $0-4$ scale, where $0=0$ (healthy), $1=$ $1-25,2=26-50,3=51-75$ and $4=76-100$ per cent. Per cent disease intensity of powdery mildew was recorded from five tagged plants from each treatment plot. An observation on per cent disease intensity of powdery mildew of bottle gourd was recorded from different treatments. Per cent disease intensity was worked out by using formula given by (Datar and Mayee, 1981) as below.

Per cent Disease Intensity $=\frac{\text { Sum of all individual ratings }}{\text { Total plants observed } \times \text { Maximum rating }} \times 100$

The per cent disease control and the percentage deviation in yield were calculated with the help of the following formula (Mathur et al., 1971).

Per cent Disease Control $(\%)=\frac{\text { PDI in control - PDI in treatment }}{\text { PDI in control }} \times 100$
Finally, the data were statistically analysed using Duncan's New Multiple Range Test (DNMRT).

\section{Results and Discussion}

All the treatments were found significantly superior over check in controlling the disease and yield (Table1). Propiconazole $(0.025 \%)$ was the most effective fungicide with 30.30 per cent least mean disease intensity followed by wettable sulphur, $(0.25 \%)$ with 33.10 per cent mean disease intensity. Tebuconazole + trifloxystrobin, dinocap, azoxystrobin and water were found moderately effective with 34.21, 36.46, 39.94 and 46.20 per cent disease intensity, respectively. Per cent disease control ranged from 19.03 to 60.78 . Maximum disease control of 60.78 per cent was observed in the treatment of propiconazole followed by wettable sulphur by 53.92 per cent as compared to control.

Maximum per cent yield increase was found in the treatment propiconazole (42.76\%) followed by wettable sulphur (38.97\%). The other treatments like tebuconazole + trifloxystrobin, dinocap, azoxystrobin, and water spray gave35.66, 34.13, 19.41 and 10.75 per cent yield increased, respectively over the control. The effectiveness of propiconazole in controlling powdery mildew in various crop viz., okra (Naik and Nagaraja, 2003), okra (Shivanna et al., 2006), coriander (Akbari and Parakhia, 2010) and sunflower (Dinesh et al., 2011) has been similar observation were reported by several workers. Dhutraj (2011) reported that wettable sulphur for controlling powdery mildew of okra. Dinocap (karathane) was found to be most effective to control powdery mildew of bottle gourd (Tripathi et al., 1995).

All natural products tested reduced the disease significantly as compared to the control (Table 2). The fermented leaf-extract 
of neem, dhatura, and sitafal (20\%) was the most effective natural products with 35.72 per cent least mean disease intensity followed by fermented cow urine, butter milk, leaves of neem, dhatura, and sitafal in combination (20 $\%$ with 37.71 per cent mean disease intensity. Fermented butter milk, fermented cow urine, bioformulation of Trichoderma harzianum $2 \times 10^{6} \mathrm{cfu} / \mathrm{g}$, and water were found moderately effective with $40.52,40.58$, 42.76 and 44.77 per cent disease intensity, respectively. Maximum disease control of 44.33 per cent was also observed in the treatment of fermented leaf-extract of neem, dhatura, and sitafal followed by treatment fermented cow urine, butter milk, leaves of neem, dhatura, and sitafal in combination by
38.96 per cent as compared to control. All natural product treatments significantly increased the bottle gourd yield as compared to control. The highest bottle gourd yield of $126 \mathrm{qt} / \mathrm{ha}$ was obtained in the treatment of fermented leaf-extract of neem, dhatura, and sitafal followed by fermented cow urine, butter milk, leaves of neem, dhatura and sitafal in combination with $106 \mathrm{qtl} / \mathrm{ha}$. The other treatments viz., fermented butter milk, fermented cow urine, bioformulation of Trichoderma harzianum $2 \times 10^{6} \mathrm{cfu} / \mathrm{g}$ and water gave significantly higher yield as compared to control. Similar observations were recorded to control the powdery mildew disease.

Table.1 Effect of different fungicides against powdery mildew of bottle gourd caused by $P$. fuliginea

\begin{tabular}{|c|c|c|c|c|c|c|}
\hline $\begin{array}{l}\text { Tr. } \\
\text { No. }\end{array}$ & Fungicides & $\begin{array}{c}\text { Conc. } \\
(\%)\end{array}$ & $\begin{array}{c}\text { Disease } \\
\text { intensity } \\
(\%)\end{array}$ & $\begin{array}{c}\text { Disease } \\
\text { control } \\
(\%)\end{array}$ & $\begin{array}{c}\text { Fruit } \\
\text { yield } \\
\text { (qtl/ha) }\end{array}$ & $\begin{array}{c}\text { Yield } \\
\text { increased } \\
(\%)\end{array}$ \\
\hline 1 & $\begin{array}{l}\text { Wettable sulphur } \\
80 \% \text { WP }\end{array}$ & 0.25 & $\begin{array}{l}29.37 * *^{\mathrm{e}} \\
(33.10)\end{array}$ & 53.92 & $136^{\mathrm{ab}}$ & 38.97 \\
\hline 2 & Dinocap $48 \%$ EC & 0.048 & $\begin{array}{l}34.87^{d} \\
(36.46)\end{array}$ & 45.30 & $126^{\mathrm{b}}$ & 34.13 \\
\hline 3 & $\begin{array}{l}\text { Propiconazole } \\
25 \% \text { EC }\end{array}$ & 0.025 & $\begin{array}{l}25.00^{f} \\
(30.30)\end{array}$ & 60.78 & $145^{\mathrm{a}}$ & 42.76 \\
\hline 4 & $\begin{array}{l}\text { Azoxystrobin } \\
25 \% \text { EC }\end{array}$ & 0.025 & $\begin{array}{l}40.75^{c} \\
(39.94)\end{array}$ & 36.08 & $103^{c}$ & 19.41 \\
\hline 5 & $\begin{array}{l}\text { Tebuconazole } \\
55 \%+ \\
\text { Trifloxystrobin } \\
25 \% \text { WG }\end{array}$ & 0.025 & $\begin{array}{l}31.25^{\mathrm{de}} \\
(34.21)\end{array}$ & 50.98 & $129^{b}$ & 35.66 \\
\hline 6 & Water spray & - & $\begin{array}{l}51.62^{b} \\
(46.20)\end{array}$ & 19.03 & $93^{\mathrm{cd}}$ & 10.75 \\
\hline 7 & Control (No spray) & - & $\begin{array}{l}63.75^{\mathrm{a}} \\
(53.27)\end{array}$ & - & $83^{d}$ & - \\
\hline & S.Em. \pm & - & 00.84 & - & 04.25 & - \\
\hline & C.D. at $5 \%$ & - & 02.49 & - & 12.64 & - \\
\hline & C.V.\% & - & 04.30 & - & 07.31 & - \\
\hline
\end{tabular}

*Figures in parentheses re-transformed values

Figures indicating common alphabets in superscript do not differ significantly at 5 per cent level of significance according to DNMRT 
Table.2 Effect of different natural products against powdery mildew of bottle gourd caused by $P$. fuliginea

\begin{tabular}{|c|c|c|c|c|c|c|}
\hline $\begin{array}{l}\text { Tr. } \\
\text { No. }\end{array}$ & Natural products & $\begin{array}{c}\text { Conc. } \\
(\%)\end{array}$ & $\begin{array}{c}\text { Disease } \\
\text { intensity } \\
(\%)\end{array}$ & $\begin{array}{l}\text { Disease } \\
\text { control } \\
(\%)\end{array}$ & $\begin{array}{l}\text { Fruit } \\
\text { yield } \\
\text { (qtl/ha) }\end{array}$ & $\begin{array}{c}\text { Yield } \\
\text { increased } \\
(\%)\end{array}$ \\
\hline 1 & Fermented cow urine & 20 & $\begin{array}{l}41.87 * \mathrm{~cd} \\
(40.58)\end{array}$ & 30.93 & $102^{\mathrm{bc}}$ & 17.64 \\
\hline 2 & Fermented butter milk & 20 & $\begin{array}{l}41.75^{\text {cd }} \\
(40.52)\end{array}$ & 31.13 & $103^{b}$ & 18.44 \\
\hline 3 & $\begin{array}{l}\text { Fermented leaf-extract of } \\
\text { neem, dhatura, sitafal }\end{array}$ & 20 & $\begin{array}{l}33.75^{\mathrm{e}} \\
(35.72)\end{array}$ & 44.33 & $126^{\mathrm{a}}$ & 33.33 \\
\hline 4 & $\begin{array}{l}\text { Fermented cow urine, butter } \\
\text { milk, leaves of (neem, } \\
\text { dhatura, sitafal) } \\
\text { in combination }\end{array}$ & 20 & $\begin{array}{l}37.00^{\mathrm{de}} \\
(37.71)\end{array}$ & 38.96 & $106^{\mathrm{b}}$ & 20.75 \\
\hline 5 & $\begin{array}{l}\text { Bioformulation of } \\
\text { Trichoderma harzianum } \\
2 \times 10^{6} \mathrm{cfu} / \mathrm{g}\end{array}$ & 0.048 & $\begin{array}{l}45.62^{b c} \\
(42.76)\end{array}$ & 24.74 & $97^{\mathrm{bc}}$ & 13.40 \\
\hline 6 & Water spray & - & $\begin{array}{l}49.12^{b} \\
(44.77)\end{array}$ & 18.97 & $92^{\text {cd }}$ & 8.70 \\
\hline 7 & Control (No spray) & - & $\begin{array}{c}60.62^{\mathrm{a}} \\
(51.43)\end{array}$ & - & $84^{\mathrm{d}}$ & - \\
\hline & S.Em. \pm & - & 1.19 & - & 3.6 & - \\
\hline & C.D. at $5 \%$ & - & 3.54 & - & 10.70 & - \\
\hline & C.V.\% & - & 5.68 & - & 7.1 & - \\
\hline
\end{tabular}

*Figures in parentheses re-transformed values

Figures indicating common alphabets in superscript do not differ significantly at 5 per cent level of significance according to DNMRT

Ragupathi et al., (1994) reported that neem oil and neem seed kernel extracts reduced incidence of Powdery mildew of Abelmoschus esculentus caused by E. cichoracearum.

Pawar and Chavan (2010) reported neem leaf extract (15\%), Parthenium leaf (10\%), Ocimum leaf (20\%), citrus leaf (20\%), Annona squamosa leaf (10\%), Ipomea (15 $\%)$ and Jowar leaf (20\%), cow urine (15\%), butter milk (20 \%) and ash spray (20\%) found effective against powdery mildew disease of cucurbits.

\section{References}

Akbari, L. F. and Parakhia, A. M. (2010). Chemical control of powdery mildew of coriander. In: $32^{\text {nd }}$ Annual Conference and Symposium on Innovation in Plant Pathology Research and Human Resource Development, Junagadh Agricultural University, Junagadh and Indian Society of Mycology and Plant Pathology, November 24-26, 2010. p. 58.

Datar, V. V. and Mayee, C. D. (1981). Assessment of loss in tomato yield due to early blight. Indian Phytopathology. 34 (2): 191-195.

Dhutraj, D. N. (2011). Efficacy of fungicides and bio-agents against powdery mildew of Okra (Erysiphe cichoracearum). Journal of Plant Disease Sciences. 6 (2): 170-172. 
Dinesh, B. M.; Kulkarni, S.; Harlapur, S. I. and Banagi, V. I. (2011). Management of sunflower powdery mildew (Erysiphe cichoracearum). Journal of Mycology and Plant Pathology. 40 (1): 49-52.

Gangopadhyay, S. (1984). Powdery mildews of cucurbits, peas, capsicum, beets and crucifers and lettuce. Advances in Vegetable Diseases. p. 123.

Naik, K. S. and Nagaraja, A. (2003). Chemical control of powdery mildew of okra. Agricultural Science Digest. 23 (4): 305-306.

Mathur, R. L.; Singh, G. and Gupta, R. B. L. (1971). Field evaluation of fungicides for the control of powdery mildew of pea. Indian Journal of Mycology and Plant Pathology. 1: 95-98.

Raghupathi, N. and Thamburaj, S. (1997). Management of powdery mildew disease of bhindi (Abelmoschus esculentus L.). South Indian Horticulture. 45 (1/2): 66-67.

Shivanna, E.; Sataraddi, A.; Janagoudar, B. S. and Patil, M. B. (2006). Efficacy of fungicides for the management of powdery mildew Erysiphe cichoracearum of okra. Indian Journal of Plant Protection. 34 (1): 85-88.

Tripathi, S. P.; Singh, R. Y. and Yadev, G. R. (1995). Chemical control of powdery mildew disease of bottle gourd. Recent Horticulture. 2 (2): 151-152.

\section{How to cite this article:}

Apurvkumar Patel, M. L. Tetarwal and Meena, R. L. 2020. Management of Powdery Mildew of Bottle Gourd (Lagenaria siceraria) through Fungicide and Natural Products. Int.J.Curr.Microbiol.App.Sci. 9(12): 644-648. doi: https://doi.org/10.20546/ijcmas.2020.912.077 